\title{
FERTILIZATION IN VITRO OF RAT EGGS AS AFFECTED BY THE MATURITY OF THE FEMALES AND THE SPERM CONCENTRATION
}

\author{
K. NIWA AND M. G. GHANG \\ Worcester Foundation for Experimental Biology, Shrewesbury, \\ Massachusetts 01545, U.S.A.
}

(Received 31st fuly 1973)

\begin{abstract}
Summary. Ovulated eggs from mature rats and superovulated eggs from immature rats were incubated with various concentrations of epididymal spermatozoa from mature rats. Few eggs from mature rats and only 16 to $20 \%$ of the superovulated eggs from immature rats were fertilized when the sperm concentration was 1.8 to $3.7 \times 10^{6}$ spermatozoa $/ \mathrm{ml}$. At concentrations of 0.7 to $1.5 \times 10^{6}$ spermatozoa $/ \mathrm{ml}$, 2 to $8 \%$ of the eggs from mature rats and $96 \%$ of the eggs from immature rats were fertilized. It appears that the eggs from the immature rats are much easier to fertilize in vitro than those from the mature rats, but the optimal concentration of spermatozoa also plays an important rôle.
\end{abstract}

After the dissolution of the zona pellucida by chymotrypsin, rat eggs can be penetrated in vitro by epididymal spermatozoa (Toyoda \& Chang, 1968). Successful fertilization in vitro of intact rat eggs with capacitated spermatozoa recovered from the uterus (Miyamoto \& Chang, 1973a, b) and of superovulated eggs from immature rats with epididymal spermatozoa (Toyoda \& Chang, $1974 \mathrm{a}$, b) has been achieved recently. The present study was designed to determine the proportion of eggs fertilized in vitro when they were recovered from mature or from immature rats and when the concentration of epididymal spermatozoa was varied.

White rats of $\mathrm{CD}$ strain descended from Sprague-Dawley rats were kept in a temperature-controlled room $\left(23\right.$ to $\left.25^{\circ} \mathrm{C}\right)$ under artificial light $(07.00$ to 19.00 hours). Spermatozoa were obtained by cutting the ducts of cauda epididymidis of adult rats (200 to 360 days old) and the sperm mass was placed in $0.5 \mathrm{ml}$ medium (Toyoda \& Chang, 1974a) covered with light paraffin oil which was equilibrated with $5 \% \mathrm{CO}_{2}$ in air before use. At 5 to $10 \mathrm{~min}$ after making this sperm suspension, $0.04 \mathrm{ml}$ was placed in $0.4 \mathrm{ml}$ of the same medium covered with paraffin oil.

Eggs were obtained from 99 to 120 day (mature) and 24- to 28-day-old rats (immature). Mature females were killed between 07.00 and 08.30 hours in the morning following pro-oestrus and their eggs were considered to have been recovered 3 to $4 \frac{1}{2} \mathrm{hr}$ after ovulation. Immature rats were induced to 
superovulate by subcutaneous injection of 10 i.u. PMSG 40 to $50 \mathrm{hr}$ before an intraperitoneal injection of $10 \mathrm{i} . \mathrm{u}$. HCG. Eggs were obtained 14 to $17 \mathrm{hr}$ after injection of HCG and were considered to have been recovered 2 to $5 \mathrm{hr}$ after ovulation. The oviducts were placed under light paraffin oil in the same dish in which the sperm suspension had been prepared in advance. Eggs in the cumulus clot were dissected from the ampullar portion of the oviducts and then introduced into the droplet of sperm suspension for fertilization in a $\mathrm{CO}_{2}$ incubator at $37^{\circ} \mathrm{C}$.

After incubation for 8 to $36 \mathrm{hr}$, the eggs were removed, mounted in toto (Chang, 1952), stained with $0.25 \%$ lacmoid, and examined for evidence of fertilization. The eggs which had spermatozoa within their perivitelline space were defined as penetrated eggs. Those which had an enlarged sperm head(s) or a male pronucleus(ei), or had cleaved with a fertilizing sperm tail(s) in the vitellus were considered to be undergoing fertilization or to be fertilized.

In Exp. 1, the eggs from mature and immature rats were incubated at the

Table 1. Fertilization in vitro of eggs from immature and mature rats as affected by the concentration of spermatozoa

\begin{tabular}{|c|c|c|c|c|c|c|}
\hline $\begin{array}{c}\text { Exp. } \\
\text { no. }\end{array}$ & $\begin{array}{l}\text { Females } \\
\text { used }\end{array}$ & $\begin{array}{l}\text { No. of } \\
\text { females }\end{array}$ & $\begin{array}{l}\text { Sperm conc. } \\
\left(10^{6} / \mathrm{ml}\right)\end{array}$ & $\begin{array}{l}\text { No. of eggs } \\
\text { examined }\end{array}$ & $\begin{array}{c}\text { No. of eggs } \\
\text { penetrated }(\%)\end{array}$ & $\begin{array}{c}\text { No. of eggs } \\
\text { fertilized }(\%)\end{array}$ \\
\hline 1 & $\begin{array}{l}\text { Mature } \\
\text { Immature }\end{array}$ & $\begin{array}{r}9 \\
19\end{array}$ & 1.8 to 3.0 & $\begin{array}{l}111 \\
713\end{array}$ & $1(0.9)$ & $0(0)$ \\
\hline 2 & Mature & 3 & $2 \cdot 3$ & 42 & $\begin{array}{c}135(18 \cdot 9) \\
0(0)\end{array}$ & $\begin{array}{c}116(16 \cdot 3) \\
0(0)\end{array}$ \\
\hline 3 & Mature & $\begin{array}{l}3 \\
3\end{array}$ & $\begin{array}{l}3 \cdot 7 \\
1 \cdot 5\end{array}$ & $\begin{array}{l}37 \\
49\end{array}$ & $\begin{array}{l}1(2 \cdot 7) \\
4(8 \cdot 2)\end{array}$ & $\begin{array}{l}0(0) \\
4(8 \cdot 2)\end{array}$ \\
\hline 4 & Mature & $\begin{array}{l}3 \\
3\end{array}$ & $\begin{array}{l}3.4 \\
0.7\end{array}$ & $\begin{array}{l}37 \\
45\end{array}$ & $\begin{array}{l}0(0) \\
2(4 \cdot 4)\end{array}$ & $\begin{array}{l}0(0) \\
1(2 \cdot 2)\end{array}$ \\
\hline 5 & Immature & $\begin{array}{l}3 \\
3\end{array}$ & $\begin{array}{l}2 \cdot 1 \\
0.7\end{array}$ & $\begin{array}{l}104 \\
122\end{array}$ & $\begin{array}{r}29(27 \cdot 9) \\
117(95 \cdot 9)\end{array}$ & $\begin{array}{r}21(20.2) \\
117(95.9)\end{array}$ \\
\hline Total & $\begin{array}{l}\text { Mature } \\
\text { Immature }\end{array}$ & $\begin{array}{l}24 \\
25\end{array}$ & $\begin{array}{l}0.7 \text { to } 3.7 \\
0.7 \text { to } 3.0\end{array}$ & $\begin{array}{l}321 \\
939\end{array}$ & $\begin{array}{c}8(2 \cdot 5) \\
281(29 \cdot 9)\end{array}$ & $\begin{array}{c}5(1 \cdot 6) \\
254(27 \cdot 1)\end{array}$ \\
\hline
\end{tabular}

same time with the same sperm preparations of the same concentration ( 1.8 to $3.0 \times 10^{6}$ spermatozoa $/ \mathrm{ml}$ ). As shown in Table 1 , of 111 ovulated eggs recovered from mature rats, only one $(0.9 \%)$ was penetrated and none was fertilized. By contrast, 135 (18.9\%) eggs were penetrated and $116(16.3 \%)$ were fertilized among 713 superovulated eggs recovered from immature rats. This shows that eggs from immature rats have a better chance of fertilization with epididymal spermatozoa in vitro than eggs from mature rats.

In Exps 2, 3 and 4, high and low concentrations of epididymal spermatozoa were prepared at the same time from the same male in each experiment for fertilization in vitro of ovulated eggs from mature rats. Table 1 shows that, of 116 eggs incubated with high concentrations $\left(2.3\right.$ to $\left.3.7 \times 10^{6} / \mathrm{ml}\right)$ of epididymal spermatozoa, only one $(0.9 \%)$ was penetrated and none was fertilized. By comparison, six $(6.4 \%)$ eggs were penetrated and five $(5 \cdot 2 \%)$ were fertilized of ninety-four eggs incubated with low concentrations $\left(0.7\right.$ to $\left.1.5 \times 10^{6} / \mathrm{ml}\right)$ of spermatozoa. These differences were highly significant when tested according 
to Fishers' exact probability test: for penetration rates, $P=0.029$ and for fertilization rates, $P=0 \cdot 017$. This result indicates that ovulated eggs from mature rats can be penetrated in vitro by incubated epididymal spermatozoa and that the eggs have a better chance of fertilization when low sperm concentrations are used.

In Exp. 5, using different concentrations of epididymal spermatozoa from the same male, fertilization in vitro of superovulated eggs from immature rats was observed. As shown in Table 1, twenty-nine $(27.9 \%$ ) eggs were penetrated and twenty-one $(20.2 \%)$ were fertilized in 104 eggs incubated with a high concentration $\left(2 \cdot 1 \times 10^{6} / \mathrm{ml}\right)$ of spermatozoa. By contrast, of 122 eggs inseminated with a low concentration $\left(0.7 \times 10^{6} / \mathrm{ml}\right)$ of spermatozoa, $117(95.9 \%)$ were penetrated and all of the penetrated eggs were fertilized.

A comparison of the fertilization rates of the total number of eggs in these five experiments shows that only five $(1.6 \%)$ of 321 ovulated eggs recovered from mature rats were fertilized, while $254(27 \cdot 1 \%)$ eggs were fertilized among 939 superovulated eggs recovered from the immature rats when sperm concentrations were between 0.7 and $3.7 \times 10^{6}$ spermatozoa/ml. It appears that ovulated eggs from mature rats are more difficult for incubated epididymal spermatozoa to penetrate in vitro.

In view of the results obtained in this study, the failure of fertilization of rat eggs in vitro with epididymal spermatozoa noted by Miyamoto \& Chang $(1973 a, b)$ may have been due to the fact that eggs from mature rats and relatively high concentrations ( 1 to $4 \times 10^{6} / \mathrm{ml}$ ) of spermatozoa were used. In fact, using low concentrations $\left(0.3\right.$ to $\left.1.4 \times 10^{6} / \mathrm{ml}\right)$ of epididymal spermatozoa and using superovulated eggs from immature rats, high proportions of eggs were fertilized in vitro (Toyoda \& Chang, 1974a, b). Since, however, the rates of fertilization in the early trials were always lower than in later trials, the experience of the researcher to conduct such an experiment must also be of importance.

By inseminating capacitated spermatozoa recovered from the uterus, the proportion of eggs fertilized in vitro was higher in the ovulated eggs from mature rats than in superovulated eggs from mature rats (Miyamoto \& Chang, $1973 \mathrm{a}, \mathrm{b})$. These results, however, are difficult to compare with those obtained in the present experiment because the source of spermatozoa used and the age of the rats induced to superovulate were different. The better chance of fertilizing eggs from the immature rats and the requirement of a lower sperm concentration for fertilization of rat eggs in vitro may be due to a difference in the properties of the zonae pellucidae surrounding the eggs of the immature and mature rats and the fact that the zona reaction can be induced to a certain extent by a large number of spermatozoa. These possibilities can be resolved only by further experimentation.

This work was supported by a grant, HD 03472, from the U.S. Public Health Service and a grant from the Ford Foundation. Thanks are due to Mrs Rose Bartke for assistance. 


\section{REFERENGES}

Chang, M. C. (1952) Fertilizability of rabbit ova and the effects of temperature in vitro on their subsequent fertilization and activation in vivo. 7. exp. Zool. 121, 351.

Mryamoto, H. \& Chanc, M. G. (1973a) In vitro fertilization of rat eggs. Nature, Lond. 241, 50.

Mryamoto, H. \& Chang, M. C. (1973b) Fertilization of rat eggs in vitro. Biol. Reprod. (in press).

Toyoda, Y. \& Chang, M. C. (1968) Sperm penetration of rat eggs in vitro after dissolution of zona pellucida by chymotrypsin. Nature, Lond. 220, 589.

Toyoda, Y. \& Ghang, M. G. (1974a) Fertilization of rat eggs in vitro by epididymal spermatozoa and the development of the eggs following transfer. 7. Reprod. Fert. 36, 9.

Toyoda, Y. \& Ghang, M. G. (1974b) Capacitation of epididymal spermatozoa in a medium with high $\mathrm{K} / \mathrm{Na}$ ratio and cyclic AMP for the fertilization of rat eggs in vitro. F. Reprod. Fert. 36, 125. 